\title{
INVESTIGATION OF A TOOL AND WORKPIECE MACHINED USING A NICKEL-NANOCOATED INSERT
}

\author{
RAZISKAVA OBRABE ORODJA IN OBDELOVANCA ZARADI \\ MEHANSKE OBDELAVE Z VLOŽKOM Z Ni-NANOPREVLEKO
}

\author{
Sureshkumar Manoj1, Veeramalai Chinnasamy Sathish Gandhi ${ }^{2}$ \\ ${ }^{1}$ TRP Engineering College (SRM Group), Department of Mechanical Engineering, Trichy, 621105, Tamilnadu, India \\ ${ }^{2}$ University College of Engineering Nagercoil, Department of Mechanical Engineering, (A Constituent College of Anna University, Chennai) \\ Nagercoil 629004, Tamilnadu, India \\ mailmanojinbox@gmail.com
}

Prejem rokopisa - received: 2017-06-11; sprejem za objavo - accepted for publication: 2017-08-03 doi: $10.17222 /$ mit.2017.071

\begin{abstract}
Most of the industrial components are machined using the turning operation. In order to sustain in the global market, the industries strive to produce precision components. One such step towards attaining precision components is the introduction of inserts. Inserts are detachable components, brazed to the working tool. The most commonly used inserts are cemented carbide inserts. However, after a few machining operations, these inserts are subjected to wear. The life of the inserts is thus reduced by the wear. In order to reduce the wear and improve the life of a tool, the inserts are coated. Coated inserts are proven to improve the mechanical properties of machined workpieces. Nevertheless, the problem still persists while machining hard-to-machine materials. Therefore, there is a need for an alternate approach. In that case, nanomaterials can be applied to improve the properties and tool life. In nanomaterials, particles with a size of $10^{-9} \mathrm{~m}$ are used, exhibiting strong bonding along the boundaries. Due to this property, the material may resist the wear, improve the tool life and mechanical properties of machined materials. In the present work, cemented carbide inserts were coated with a nickel nanomaterial using the physical vapour deposition (PVD) technique, as nickel exhibits a high wear resistance and it is a hard material. The results showed that nickel-nanocoated inserts improve the tool life by reducing the wear of the inserts and the surface roughness of a machined workpiece as compared with uncoated inserts.
\end{abstract}

Keywords: inserts, coatings, nickel (Ni), nanomaterials, SEM, Taguchi method

Večina industrijskih komponent je mehansko obdelanih s struženjem ali rezkanjem. Zato, da bi se določeno podjetje obdržalo na globalnem trgu, mora skrbeti za čimvečjo natančnost svojih izdelkov. Eden od načinov je uvajanje čim boljših vložkov (rezalnih ploščic) za mehansko obdelavo. Vložki so ločljive komponente, ki so običajno mehansko pritrjene na delovno orodje (nož). Najbolj pogosto uporabljene rezalne ploščice so izdelane iz karbidnih trdin. Le-te se med mehansko obdelavo obrabljajo. Zaradi mehanske obrabe je njihova doba trajanja skrajšana. Da bi zmanjšali obrabo rezalnih ploščic in podaljšali njihovo dobo trajanja, so le-te običajno prevlečene s trdo prevleko. Prevlečene rezalne ploščice dokazano izboljšajo mehanske lastnosti obdelovanca. Vendar problemi še ostajajo, če je potrebno mehansko obdelovati trde in težko obdelovalne materiale. Zato so potrebni alternativni pristopi z uporabo nanoprevlek. Nanomateriali so sestavljeni iz delcev reda velikosti $10^{-9} \mathrm{~m}$, ki imajo močno medsebojno vez. Zaradi tega se lahko močneje upirajo obrabi, kar podaljša življenjsko dobo rezalnega orodja in izboljša mehanske lastnosti obdelovancev. V pričujočem delu avtorji opisujejo uporabo rezalnih ploščic iz karbidne trdine, ki so bile prevlečene s prevleko iz nano Ni. Prevleka je bila izdelana s fizikalnim postopkom nanašanja iz parne faze (PVD; angl.: Physical Vapor Deposition). $\mathrm{Ni}$-nanoprevleka je trda in zato visoko obrabno odporna. Rezultati raziskave so pokazali, da imajo rezalne ploščice prevlečene z Ni-nanoprevleko precej boljšo odpornost proti obrabi, v primerjavi z neprevlečenimi rezalnimi ploščicami, kar precej podaljša njihovo dobo trajanja in zmanjša hrapavost obdelovanca.

Ključne besede: rezalne ploščice, prevleke, nikelj (Ni), nanomateriali, SEM, Taguchi metoda

\section{INTRODUCTION}

Machining is a process where raw materials are made into a desired product using a controlled process of material removal. Turning is a type of the machining process where a non-rotary tool-bit-type cutting tool defines the helical tool path. ${ }^{1}$ In earlier days, a turning operation was carried out manually. It required highly skilled labour and close monitoring. Constant supervision was required. Later this type of turning was replaced with computer numerical control lathes. To make their name short, they were called CNC lathes and they are still widely used nowadays. The speed, feed and depth of a cut are the three prime machining parameters of a turning operation. ${ }^{2}$ The speed generally refers to the workpiece and spindle speed. The unit of measurement is revolution per minute $\left(\mathrm{min}^{-1}\right)$.

The feed is defined as the relative velocity, at which the cutter advances the workpiece. Its direction vector is perpendicular to that of the cutting speed. The unit of feed rate is dependent on the workpiece and the motion of the tool. Generally, the unit of feed in a turning operation is distance per spindle revolution $(\mathrm{mm} / \mathrm{min})$. The feed rate is the most influential process parameter that influences the metal-removal $\operatorname{rate}^{3}(M R R)$. The depth of cut is the amount of material, which is removed in single cut. The unit of measurement is millimetre $(\mathrm{mm})$. Nowadays inserts are widely used for turning operations. Inserts are detachable cutting tips. They are not brazed or welded to the tool. Inserts are normally indexable as they 
can be flipped or rotated without affecting the overall geometry of the tool. The time wasted for set-up changes, new input values for $\mathrm{CNC}$ lathes and tool grinding can be avoided with the inserts that are periodically changed.

An experimental investigation conducted in the machining of the AISI 310 austenitic stainless steel with titanium-carbide cutting tools showed the effects of machining parameters on the built-up-layer (BUL) and built-up-edge (BUE) formation and the wear behaviour of the cutting tools. ${ }^{4}$ The highest accumulations of the BUL and the BUE were observed at low cutting speed, feed rate and cutting depth. Researches revealed that a multilayer TiN/TiCN/Al $\mathrm{O}_{3} / \mathrm{TiN}$-coated insert performed better than the uncoated inserts. ${ }^{5}$ Also, a carbide-coated insert exhibits machinability with a better surface finish. ${ }^{6}$ When the optimum condition is chosen, it lowers the flank wear and surface roughness with a higher $M R R .^{7}$

The application of nanotechnology in the coating field proved to be profitable. The materials exhibit new behaviours and properties at a nanoscale. The range of nanoscale varies from $1 \mathrm{~nm}$ to $100 \mathrm{~nm}$. It takes skill to utilize these nanoprinciples. A sincere effort is needed to manipulate and control nanomaterials in a better way. The properties of materials such as electrical conductivity, heat conductivity, magnetic properties, hardness, etc., can be improved by varying the size of the particles within the nanoscale. Surface areas of nanoscale materials are larger when compared with larger-scale materials of similar volumes. The surface interacting with the other materials around them is large in the case of nanoscale materials. A better tool life is achieved when adaptive nano-multilayered coating is done. ${ }^{8}$

From the literature study, it was evident that the tool life, wear resistance and hardness can be improved by coating the tool and inserts. ${ }^{9}$ Also, nanomaterials have low friction and good wear resistance ${ }^{10}$ as compared to ordinary coatings. It was also seen from the literature that silicon, titanium and zirconium coatings are presently used to improve the life of inserts. Nickel is a harder material, whose particles, at a nanoscale, exhibit better mechanical properties than those of $\mathrm{SiO}_{2}$, Ti or $\mathrm{Zr}$.

\section{EXPERIMENTAL PART}

The experimental work was carried out in a computer-numerical-control (CNC) lathe machine. ${ }^{11}$ The CNC lathe, in which the experiments were carried out, is shown in Figure 1.

The CNMG 120408 tool (C-shape, N-clearance angle, M-tolerance, G-groove/hole) was chosen as the insert. The workpiece machined using CNMG inserts exhibited a lower surface-roughness value than TNMG and WNMG inserts. Then the machining was carried out under different cutting conditions. During the machining, the machining time was noted.
The inserts were then coated with the nickel nanomaterial using the physical-vapour-deposition technique ${ }^{12}$ (PVD). The PVD technique is preferred over CVD since PVD coatings are thin but still tougher and smoother. Various properties of the nickel nanomaterial are shown in Table 1.

Table 1: Properties of nickel nanoparticles ${ }^{13,14}$

\begin{tabular}{|c|c|}
\hline Chemical symbol & $\mathrm{Ni}$ \\
\hline CAS No. & $7440-02-0$ \\
\hline Group & 4 \\
\hline Electronic configuration & $(\mathrm{Ar}) 3 \mathrm{~d} 8 \mathrm{~s} 2$ \\
\hline Molar mass & $58.69 \mathrm{~g} / \mathrm{mol}$ \\
\hline Melting point & $1453^{\circ} \mathrm{C}$ \\
\hline Boiling point & $2732^{\circ} \mathrm{C}$ \\
\hline
\end{tabular}

The radio-frequency (RF) sputtering technique, which is one of the physical-vapour-deposition processes, was used for applying nanomaterials on the inserts. The RF sputtering technique was used as it effectively and evenly applies the material over the substrate. Table 2 shows the experimental data for the turning operation.

Table 2: Experimental data for the turning operation

\begin{tabular}{|l|c|c|c|}
\hline \multicolumn{1}{|c|}{ Process parameter } & Level 1 & Level 2 & Level 3 \\
\hline Speed in $\mathrm{min}^{-1}$ & 1200 & 1600 & 2000 \\
\hline Feed in mm/rev & 0.18 & 0.24 & 0.28 \\
\hline Depth of cut in mm & 0.4 & 0.8 & 1.2 \\
\hline
\end{tabular}

The Taguchi method was used for determining the number of experiments. ${ }^{15}$ The Taguchi method provides an experimental design, involving orthogonal arrays, to organize the parameters that affect the process and its different levels. Since factorial design consumes more time and resources, the $L 9$ orthogonal array is a more effective method than factorial design. Unlike the factorial design where all possible combinations are tested, only pairs of combinations are tested with the Taguchi method. This helps us determine the factors that affect the product quality using the minimum number of experiments. So, it saves time and resources. Here, the Taguchi $L 9$ orthogonal array is chosen, as there are three

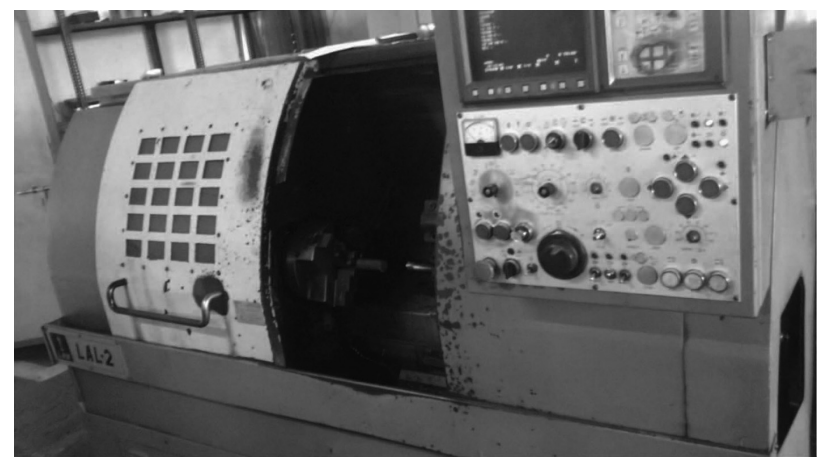

Figure 1: CNC lathe 
parameters and three levels. Table 3 shows the experimental design using the $L 9$ orthogonal array.

Table 3: Experimental design using $L 9$ orthogonal array

\begin{tabular}{|c|c|c|c|}
\hline \multirow{2}{*}{$\begin{array}{c}\text { Experiment } \\
\text { No. }\end{array}$} & \multicolumn{3}{|c|}{ Levels } \\
\cline { 2 - 4 } & Speed in $\mathrm{min}^{-1}$ & $\begin{array}{c}\text { Feed in } \\
\mathrm{mm} / \mathrm{rev}\end{array}$ & $\begin{array}{c}\text { Depth of cut in } \\
\mathrm{mm}\end{array}$ \\
\hline 1 & 1200 & 0.18 & 0.4 \\
\hline 2 & 1200 & 0.24 & 0.8 \\
\hline 3 & 1200 & 0.28 & 1.2 \\
\hline 4 & 1600 & 0.18 & 0.4 \\
\hline 5 & 1600 & 0.24 & 0.8 \\
\hline 6 & 1600 & 0.28 & 1.2 \\
\hline 7 & 2000 & 0.18 & 0.4 \\
\hline 8 & 2000 & 0.24 & 0.8 \\
\hline 9 & 2000 & 0.28 & 1.2 \\
\hline
\end{tabular}

A surface-roughness tester was used to measure the surface-roughness value and a SEM test was conducted to study the wear that occurred on the coated and uncoated inserts.

\section{RESULTS AND DISCUSSION}

The experiments were chosen using the Taguchi $L 9$ orthogonal array and the turning operation was conducted in a CNC lathe with a CNMG insert coated with nickel nanoparticles as shown in Table 4.

Table 4: Surface-roughness comparison between coated (nickel-nanocoated) and uncoated inserts

\begin{tabular}{|c|c|c|c|c|c|}
\hline \multirow{2}{*}{ S. No. } & \multirow{2}{*}{$\begin{array}{c}\text { Speed in } \\
\mathrm{min}^{-1}\end{array}$} & $\begin{array}{c}\text { Feed in } \\
\mathrm{mm} / \mathrm{rev}\end{array}$ & $\begin{array}{c}\text { Depth of } \\
\text { cut in mm }\end{array}$ & $\begin{array}{c}\text { Surface roughness } \\
\text { in microns }\end{array}$ \\
\cline { 5 - 6 } & & & & Coated & Uncoated \\
\hline 1 & 1200 & 0.18 & 0.4 & 0.8 & 1.6 \\
\hline 2 & 1200 & 0.24 & 0.8 & 1.6 & 3.2 \\
\hline 3 & 1200 & 0.28 & 1.2 & 3.2 & 6.3 \\
\hline 4 & 1600 & 0.18 & 0.4 & 0.4 & 0.8 \\
\hline 5 & 1600 & 0.24 & 0.8 & 1.6 & 3.2 \\
\hline 6 & 1600 & 0.28 & 1.2 & 6.3 & 12.5 \\
\hline 7 & 2000 & 0.18 & 0.4 & 0.8 & 1.6 \\
\hline 8 & 2000 & 0.24 & 0.8 & 1.6 & 3.2 \\
\hline 9 & 2000 & 0.28 & 1.2 & 6.3 & 12.5 \\
\hline
\end{tabular}

From the above Table 4 we can see that the surface roughness increases with increases in the speed, feed and depth of cut. It is evident that the surface roughness of the workpiece machined with the nickel-nanocoated inserts is far better compared with the uncoated inserts. It is observed that for the coated inserts at a speed of $1600 \mathrm{~min}^{-1}$, feed rate of $0.18 \mathrm{rev} / \mathrm{mm}$ and depth of cut of $0.4 \mathrm{~mm}$, the surface roughness is 0.4 microns. For the uncoated inserts, the surface roughness is 0.8 microns. It is seen that the surface roughness of the coated inserts is lower by $50 \%$ when compared with the uncoated inserts. This is the minimum surface-roughness value obtained. So, the corresponding process parameters are considered to be the optimum conditions.
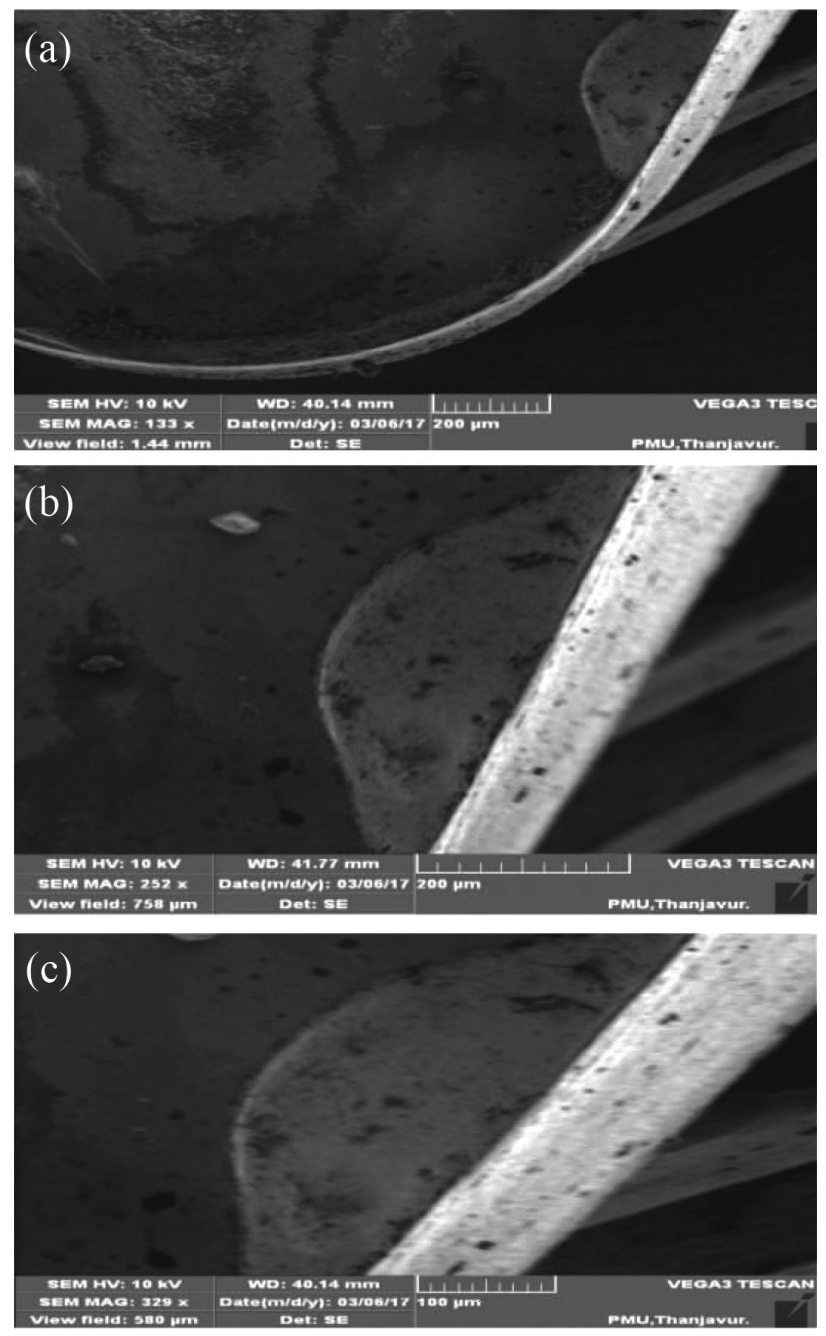

Figure 2: a), b) and c) SEM images of the uncoated insert at different levels of zoom

Nickel nanocoating withstands the temperature during the machining. Nickel nanocoating reduces the temperature generated during the machining. The nickel nanocoating on the inserts not only improved the surface roughness but also improved the wear resistance of the inserts. A scanning electron microscope (SEM) analysis of the tool inserts was done. Both the uncoated insert and the nickel-nanocoated insert were studied with the SEM analysis. Transmission electron microscopy (TEM), $\mathrm{X}$-ray diffraction (XRD) and energy-dispersive X-ray analysis (EDX) are the other methods that can be used to study the wear surface of a tool. SEM images of the coated and uncoated inserts at various magnification levels are shown in Figures 2a, 2b, 2c and 3a, 3b, 3c.

The SEM images of the uncoated insert show that crater wear occurs on the rake face of the tool, which causes a change in the tool-chip interface geometry. This affects the cutting process. The major factors that cause crater wear are the temperature at the tool-chip interface and the chemical magnetism between the workpiece material and the tool. It is thus tri-biochemical wear due 

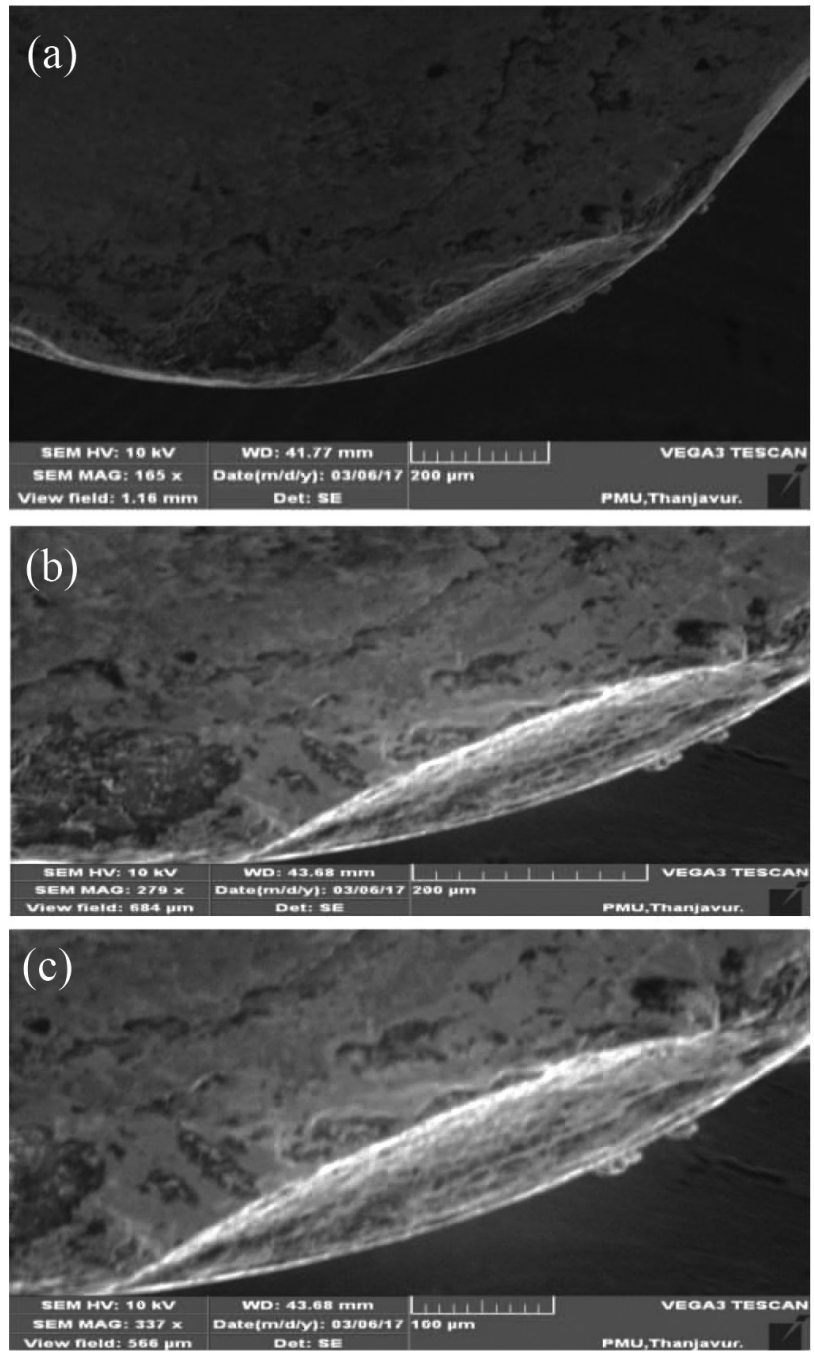

Figure 3: a), b) and c) SEM images of the nickel-nanocoated insert at different levels of zoom

to the chemical affinity between the cutting-tool materials and the workpiece materials. The life of the tool is also reduced. Figures 3a, 3b and 3c show SEM images of the nickel-nanocoated insert at different levels of zoom.

Figures 3a, $\mathbf{3 b}$ and $\mathbf{3 c}$ shows that the crater-wear formation is smaller. The nickel coating binds well to the tungsten-carbide substrate and no peel off is seen. Therefore, the life of the insert is improved due to a higher wear resistance.

\section{CONCLUSIONS}

A nickel nanomaterial was successfully applied over a tungsten-carbide insert using RF sputtering of the PVD technique. The number of experiments was chosen using the Taguchi method. Then the workpiece was machined with both uncoated and nickel-nanocoated tool. SEM images of the uncoated and nickel-nanocoated inserts were studied. From the above discussion, it is concluded that:
- the workpiece machined with the nickel-nanocoated insert exhibits a low surface roughness when compared with the uncoated insert;

- the uncoated carbide insert wears out more quickly than the nickel-nanocoated insert; so the nickel nanocoating improves the life of the insert;

- the optimum parameters for the minimum surfaceroughness value are obtained.

\section{REFERENCES}

${ }^{1}$ G. Bartarya, S. K. Choudhury, State of the art in hard turning, International Journal of Machine Tools \& Manufacture, (2012) 53, 1-14, doi:10.1016/j.ijmachtools.2011.08.019

${ }^{2}$ B.Varaprasad, C.Srinivasa Rao, P. V. Vinay, Effect of Machining Parameters on Tool Wear in Hard Turning of AISI D3 Steel, 12th Global Congress On Manufacturing And Management, 97 (2014), 338-345, doi:10.1016/j.proeng.2014.12.257

${ }^{3}$ B. Rajendra, D. Deepak, Optimization of Process Parameters for Increasing Material Removal Rate for Turning Al6061 Using S/N ratio, International Conference on Emerging Trends in Engineering, Science and Technology, 24 (2016), 399-405, doi:10.1016/j.protcy. 2016.05.055

${ }^{4}$ M. B. Bilgin, Investigating the Effects of Cutting Parameters on the Built-Up-Layer and Built-Up-Edge Formation during The Machining of AISI 310 Austenitic Stainless Steels, Mater.Tehnol., 49 (2015) 5, 779-784, doi:10.17222/mit.2014.253

${ }^{5}$ A. K. Sahoo, B. Sahoo, Experimental investigations on machinability aspects in finish hard turning of AISI 4340 steel using uncoated and multilayer coated carbide inserts, Measurement, 45 (2012), 2153-2165, doi:10.1016/j.measurement.2012.05.015

${ }^{6}$ B. Pazhanivel, T. P. Kumar, G. Sozhan, Machinability and scratch wear resistance of carbon-coated WC inserts, Materials Science and Engineering B, 193 (2015), 146-152, doi:10.1016/j.mseb.2014. 12.006

${ }^{7}$ N. Senthilkumar, T. Tamizharasan, Effect of Tool Geometry in Turning AISI 1045 Steel: Experimental Investigation and FEM Analysis, Arabian Journal for Science and Engineering, 39 (2014), 4963-4975, doi:10.1007/s13369-014-1054-2

${ }^{8}$ A. Biksa, K. Yamamoto, G. Dosbaeva, S. C. Veldhuis, G. S. Fox-Rabinovich, A. Elfizy, T. Wagg, L. S. Shuster, Wear behavior of adaptive nano multilayered AlTiN/MexN PVD coatings during machining of aerospace alloys, Tribology International, 43 (2010), 1491-1499, doi:10.1016/j.triboint.2010.02.008

${ }^{9}$ A. Attanasioa, E. Ceretti, A. Fiorentinoa, C. Cappellinia, C. Giardinib, Investigation and FEM-based simulation of tool wear in turning operations with uncoated carbide tools, Wear, 269 (2010), 344-350, doi:10.1016/j.wear.2010.04.013

${ }^{10}$ L. H. Moreno, J. C. Ciacedo, F. Martinez, G. Bejarano, T. S. Battaille, P. Prieto, Wear Evaluation of WC Inserts Coated with TiN/TiAlN Multi nano layers, Journal of the Brazilian Society of Mechanical Science and Engineering, 32 (2010), 2, doi:10.1590/ S1678-58782010000200003

${ }^{11}$ E. Uhlmann, J. A. Oyanedel Fuentes, M. Keunecke, Machining of high performance workpiece materials with CBN coated cutting tools, Thin Solid Films, 518 (2009), 1451-1454, doi:10.1016/ j.tsf.2009.09.095

${ }^{12}$ M. Nalbant, H. Gokkaya, I. Toktas, G. Sur, The experimental investigation of the effects of uncoated, PVD- and CVD-coated cemented carbide inserts and cutting parameters on surface roughness in $\mathrm{CNC}$ turning and its prediction using artificial neural networks, Robotics and Computer-Integrated Manufacturing, 25 (2009), 211-223, doi:10.1016/j.rcim.2007.11.004

${ }^{13}$ A. Sohrabi, A. Dolati, M. Ghorbani, A. Monfared, P. Stroeve, Nano mechanical properties of functionally graded composite coatings: 
Electrodeposited nickel dispersions containing silicon micro- and nano particles, Materials Chemistry and Physics, 121 (2010), 497-505, doi:10.1016/j.matchemphys.2010.02.014

${ }^{14}$ M. Srivastava, J. N. Balaraju, B. Ravishankar, K. S. Rajam, Improvement in the properties of nickel by nano- $\mathrm{Cr} 2 \mathrm{O} 3$ incorporation, Surface \& Coatings Technology, 205 (2010), 66-75, doi:10.1016/ j.surfcoat.2010.06.004

${ }^{15}$ N. Senthilkumar, T. Tamizharasan, V. Anandakrishnan, Experimental investigation and performance analysis of cemented carbide inserts of different geometries using Taguchi based grey relational analysis, Measurement, 58 (2014), 520-536, doi:10.1016/j.measurement. 2014.09.025 